NBER WORKING PAPER SERIES

\title{
TRADE WARS: \\ THE EXAGGERATED IMPACT OF TRADE \\ IN ECONOMIC DEBATE
}

\author{
Richard B. Freeman \\ Working Paper 10000 \\ http://www.nber.org/papers/w10000
NATIONAL BUREAU OF ECONOMIC RESEARCH 1050 Massachusetts Avenue
Cambridge, MA 02138
September 2003

The views expressed herein are those of the authors and are not necessarily those of the National Bureau of Economic Research.

(C)2003 by Richard B. Freeman. All rights reserved. Short sections of text, not to exceed two paragraphs, may be quoted without explicit permission provided that full credit, including (C) notice, is given to the source. 
Trade Wars: The Exaggerated Impact of Trade in Economic Debate

Richard B. Freeman

NBER Working Paper No. 10000

September 2003

JEL No. J0, J5

\begin{abstract}
$\underline{\text { ABSTRACT }}$
The rules governing trade and capital flows have been at the center of controversy as globalization has proceeded. One reason is the belief that trade and capital flows have massive effects on the labor market - either positive, per the claims of international financial institutions and free trade enthusiasts, or negative, per the ubiquitous protestors at WTO, IMF, and World Bank meetings demanding global labor standards. Comparing the claims made in this debate with the outcomes of trade agreements, this paper finds that the debate has exaggerated the effects of trade on economies and the labor market. Changes in trade policy have had modest impacts on labour market. Other aspects of globalization - immigration, capital flows, and technology transfer - have greater impacts, with volatile capital flows creating great risk for the well-being of workers. As for labor standards, global standards do not threaten the comparative advantage of developing countries nor do poor labor standards create a "race to the bottom".

Richard B. Freeman

NBER

1050 Massachusetts Avenue

Cambridge, MA 02135

and Harvard University

freeman@nber.org
\end{abstract}




\section{Introduction}

The trade war in my title does not refer to the current battles between the US and EU over GM-foods or bananas or steel or aircraft, but to the battle among economists, policy-makers, and activists over trade and globalization in the modern economic world. Many economists and the international financial institutions (IFIs) responsible for the global economy argue that free trade and open capital markets are the key to economic success. Other economists, many NGO activists, and the ubiquitous protestors at WTO, IMF, and World Bank meetings believe that trade and globalization can destroy jobs and create poverty and inequality unless they are married to broader social objectives (See Deardorff, 2003). Since neither side advocates autarky, the argument is over the kind of globalization that would work best for the world: the orthodox brand, based on free trade and capital mobility (but not free immigration) embodied in the Washington Consensus (WC), with safeguards for capital and intellectual property versus a more structured or managed globalization, with safeguards for labour and the environment (but not free immigration).

The battle is largely empirical, albeit informed by relevant trade theory and models, and marked by passionate rhetoric that economists usually eschew. The passion reflects the one thing on which adherents and opponents of WC globalization agree - that trade and trade policies have a huge impact on economic outcomes and, in particular, on how workers fare in the labour market.

\section{Battles}

Indicative of the importance that the two sides accord trade and globalization, consider the arguments over the following trade treaties:

- In the early 1990s, when the European Community removed intra-European 
barriers to trade, the US feared that an enhanced Common Market (EC 1992) would divert trade between the US and Europe, reducing American exports and jobs, while hoping that an ECdriven expansion would increase demand for US goods and workers. The key EU document on the single market, Cecchini (1988) predicted that EC 1992 would raise European GDP by 4-5\% percent (midpoint of a range of estimates) while Baldwin (1989) estimated that permanent increases in growth would produce a present value gain of GDP of 11 to 35 percent. In 2002 the EU Internal Market Commissioner declared that "The Single Market has transformed Europe beyond recognition in ten years. It has created millions of jobs and hundreds of billions of euros of extra prosperity. But the next decade will be no less crucial." ${ }^{1}$ In fact, from 1992 to 2002 the EU performed less well than in the preceding decade, while the US had a remarkable boom in the late 1990 s. $^{2}$

- In the late 1980s Canadians debated the Canadian-American Free Trade Agreement. Canada hoped that reduced tariffs would raise productivity and increase foreign direct investment and would secure access to the US market. Prime minister Brian Mulroney promised "jobs, jobs, jobs" while his negotiators predicted pay increases for Canadian workers. Opposing the treaty, unions worried about businesses relocating to the United States in industries where economies of scale gave the US an edge and job losses in other sectors where Canadian plants were less productive than American plants. Canadian nationalists feared that increased economic integration would threaten Canadian culture and sovereignty. Almost immediately after signing the Treaty, Canada suffered its worst economic slide since the Great Depression. Most Canadian economists blame the 1990s slide on poor macro-economic policies, though

\footnotetext{
${ }^{1}$ Frits Bolkestein, http://europa.eu.int/comm/internal_market/10years/index_en.htm ${ }^{2}$ Deardorff, Alan and Robert Stern, "EU Expansion and EU Growth" "conclude that evidence for increased long run growth rates of the EU countries is weak", introduction, http://www.fordschool.umich.edu/rsie/workingpapers/Papers476-500/r487.pdf
} 
some argue that the government's free trade stance affected those policies. ${ }^{3}$ In any case, other economic forces trumped whatever positive effects the trade agreement had on Canada. ${ }^{4}$

- The struggle in the US over NAFTA in 1992-1994 pitted the Clinton

Administration and business community against the AFL-CIO and diverse other groups, with Ross Perot playing a critical role. At the heart of the debate was how the treaty would affect jobs and wages. On the basis of forecasts of a huge trade surplus with Mexico, the Administration promised that NAFTA would create 200,000 jobs per year. ${ }^{5}$ Perot claimed that the treaty was going to cost the US 4\% of employment (the great sucking sound of jobs moving to Mexico) and encourage illegal immigration. ${ }^{6}$ Economists focused more on potential wage effects. Bhagwati argued that the treaty would not affect wages on the grounds that trade was uncorrelated with relative prices. ${ }^{7}$ Borjas, Katz, and Freeman's (1997) factor content analysis estimated that trade had small adverse effects on the wages of low skill workers. The Administration and the business press warned that if the Congress were to reject the Treaty, the Mexican economy would collapse (See Lee, 1995). Shortly after Congress passed the Treaty, the Mexican economy collapsed. Following the 1994 peso crisis, the US trade surplus with Mexico fell, which by the calculations used in the debate, would have cost the US 700,000 jobs. But no one complained. The late 1990s boom trumped whatever effects NAFTA had on employment. (See

\footnotetext{
${ }^{3} \mathrm{http}: / /$ strategis.ic.gc.ca/sc_ecnmy/mera/engdoc/02f.html

${ }^{4}$ While the benefits of NAFTA for Canada have not been well documented, the Ipsos -Reid June 2003 opinion poll shows that $70 \%$ of Canadians support Canada's involvement with NAFTA and believe the growing together of the Canadian and US economies is good. Half of Canadians believe the Treaty has benefitted Canada, while a quarter think it hurt Canada. http://www.ipsos_reid.com/media/dsp_displaypr_cdn.cfm?id_to_view=1839

${ }^{5}$ This is based on an estimate by Hufbauer and Schott of 170,000 jobs (rounded to 200,000) that also predicted increasing wages and employment in Mexico. After the Mexican peso collapse, Hufbauer said "The lesson for me is to stay away from job forecasting", as quoted in Lee, $\mathrm{p} 11$.

${ }^{6}$ At a conference, I noted that since most US workers were in non traded sectors and only a small number were in industries for which Mexico was a good competitor, these claims had to be wrong. An industry spokesman took me aside and offered a sizeable sum of money to support research debunking the effect of trade on employment.

${ }^{7}$ If trade had no effect on relative prices, it presumably benefitted no one either. But in fact trade does affect relative prices and benefits some at the expense of others.
} 
Lee, 1995$)^{8}$

- In 1995-1998 battle raged over the OECD’s proposed multilateral agreement on investment (MAI). Multinational firms wanted protection against being treated differently than domestic firms, the ability to sue governments for losses from national environmental and other legislation, and binding international arbitration for disputes with countries. Many economists favored the treaty in the hope that these provisions would increase the flow of foreign direct investment to LDCs. Opponents alleged that the MAI would shift power from LDC governments to multinational corporations. They coordinated campaigns against the treaty in more than half of OECD countries and numerous developing countries. In 1998 the OECD scuttled the treaty when France backed out under pressure from French protestors. Absent the MAI, from 1995 to 2001, foreign direct investment FDI to LDCs averaged $0.6 \%$ of advanced country GDP compared to $0.2 \%$ in the preceding five years (See Dobson and Hufbauer, 2001).

- The late 1990s/early 2000s trade war focused on linking environmental and labor standards with trade. Demonstrators at world economic summits demanded labour and environmental standards clauses in trade agreements with enforcement by trade sanctions while most developing country governments feared that standards were protectionism in disguise $-\mathrm{a}$ plot to lock LDCs out of world markets. Some NGOs demanded debt reduction for highly indebted countries, while their opponents raised issues of moral hazard with such policies.

\section{An Alternative View}

At the heart of the trade wars is the belief that changes in trade arrangements have huge

\footnotetext{
${ }^{8}$ Public opinion in the US has been generally favorable to NAFTA, though when given an option "haven't heard enough to say" over half of one survey chose that response. See P. Warf and S. Kull, "Tepid Traders: US public attitudes on NAFTA and Free Trade Expansion", http://www.bus.ualberta.ca/CIBSWCER/WCER/NAFTAwarf.pdf. Support for trade continued after 9/11, see http://www.southern.org/pubs/Post_9_11.pdf
} 
impacts on economies and on labor markets and worker well-being. Adherents to WC style globalization believe that developing countries can only grow through exports and openness. They fear that LDC trade with advanced countries is so fragile that it must be protected from global labor standards. Opponents believe that good labor standards are so fragile that they must be protected from a race to the bottom, in which bad standards drive out good standards.

While complete autarky or imposition of advanced country standards on LDCs would have huge effects on economies around the world, the actual policies around which debate has focused and observed changes in trade patterns have not come close to having their ballyhooed or feared effects on labor markets or on economies writ large. Both the proponents and opponents of globalization WC style have exaggerated the importance of trade. Instead of dominating economic outcomes, changes in trade policy and trade have had modest impacts on labour market and economic outcomes beyond trade flows. Other aspects of globalization immigration, capital flows, and technology transfer - have greater impacts on the labour market, with volatile capital flows creating great risk for the well-being of workers. As for labour standards, global standards do not threaten the comparative advantage of developing countries nor do poor labour standards create a "race to the bottom". Globalization and standards are complementary rather than competing activities.

Trade-a modest factor in economic growth? Mobility of capital - a threat to developing countries? Labour standards - complementary with globalization?

A decade or so ago, most trade economists, especially those associated with IFIs, would have dismissed claims like these as the blathering of some populist nut - or perhaps a labour economist who doesn't know Heckscher from Ohlin or Samuelson-Stolper and who cannot spell 
Rybicinski properly. ${ }^{9}$ Today, the situation is different. The 1990 s experience with globalization, recurrent financial crises, and the economic collapse of the 1990s poster country for globalization, Argentina, has shaken orthodox claims. Dani Rodrik's critiques of globalization, Jeffrey Sach's criticism of IMF policies in the Asian financial crisis, and attacks on Bank and IMF policies from insiders such as Joseph Stiglitz and William Easterly have forced the adherents of globalization WC style on the defensive. Defenders of the orthodoxy now proclaim the virtues of globalization more guardedly and wonder whether the advantages of free capital flows outweigh the disadvantages. The Managing Director of the IMF accepts the notion that labour standards are a positive force in the global economy - at least in a seminar in Germany. ${ }^{10}$

\section{Trade - A modest contributor to economic progress?}

Studies of the impact of trade and trade policies on economies consist of: postmortems on trade treaties; cross-country regressions that relate GDP, poverty, and income inequality to measures of trade or openness; and case studies of country experiences.

\section{Postmortems}

Postmortems on trade treaties compare actual outcomes to the outcomes that supporters or opponents of the treaties promised. Because other economic factors change, postmortems must go beyond simple before/after comparisons to control for non-treaty related determinants of outcomes. The harder it is to control for other factors, the more likely it is that the treaties are less powerful determinants of outcomes than proponents or opponents proclaimed. One way to

\footnotetext{
${ }^{9}$ In 1992, when I gave a talk at the annual World Bank research conference arguing that labor markets and labor market institutions were not the cause of developing country problems - surely a less controversial claim - Larry Summers imported three ILO economists "to protect me" from Bank economists. The three heavies were not needed since most Bank economists in fact agreed with the claim. But had I said that trade was not important and that open capital markets did more harm than good, I would have needed Hulk Hogan and Andre the Giant to save me from enraged IFI economists.

10 "We also need a corporate code of ethics that fosters sustainable value creation that takes into account shareholders, workers, and the environment," Horst Köhler, "The Challenges of Globalization and the Role of the IMF" at the Annual Meeting of the Society for Economics and Management at Humboldt University Berlin, May
} 
isolate the effect of a treaty is to compare outcomes in sectors/groups more/less impacted by the treaty, on the assumption that other factors treated the sectors similarly. Trefler (2001)goes one step further in analysing the Canadian-US free trade treaty by contrasting changes in 4-digit Canadian industries that had great reductions in tariffs with changes in other industries, relative to a cyclically similar period prior to NAFTA - a difference in difference analysis. He found that the most impacted industries had substantial falls in sales and employment, with the loss of employment exceeding the loss of sales, producing an improvement in productivity. He interpreted this as showing that the treaty had "very large transition costs" (p. 19) but had long run gains in productivity, much from plant closure. This fits the experience of the importsubstituting sector, but does not fit the entire economy. Over the entire decade Canadian productivity did not improve, despite the rapid increase in imports and exports, so that the question exercising Canadians in 2002 was the continued productivity deficit versus the US. ${ }^{11}$

Tybout and Erdom (2003) summarize work that uses micro-enterprise or firm data to examine the effects of five trade liberalizing experiences in LDCs: Brazil, 1991-1994; Mexico (1984-89); India (1991); Cote D'Ivoire (1985-87); Chile (1973-79). Virtually all of the studies find that productivity rises in import-competing sectors, consistent with Trefler. In some cases they attributed the increased productivity to the exit of less efficient importers, in other cases firms invested in capital or squeezed inefficiencies out of their production process. But in no country was the liberalization episode followed by a noticeable change in the growth rate. From the data on growth, you could not identify that there had been a policy change. ${ }^{12}$

After the passage of NAFTA, the US government moderated its claims about NAFTA to

15,2003

${ }^{11} \mathrm{http} / / / \mathrm{www}$. dfait maeci.gc.ca/nafta alena/over en.asp provides a summary

12 Andrews, Donald, "Tests for Parameter Instability and Structural Change With an Unknown Change Point," Econometrica, vol 61, no 4, July 1993, pp 821-856. 
“a modest positive effect on U.S. net exports, income, investment and jobs supported by exports", estimating that "jobs associated with exports to Mexico between roughly 90,000 and 160,000", with no assessment of job losses due to imports. Opponents argued that the US had lost some 766,000 jobs due to worsened trade deficit with Mexico and Canada.(See Scott, 2001) Mexican critics of NAFTA suggested that the sizeable post-NAFTA shift of employment to the informal sector was due to the treaty ${ }^{13}$ and blamed trade for some of Mexico's increase in inequality. In fact, micro studies have attributed some of the rise in earnings inequality in Mexico to trade (Feliciana (2001), Hanson (2003), Hanson and Harrison (1999)). More broadly, increased trade is associated with rising inequality in earnings in many LDCs, particularly in Latin America (Robbins (1994), Green et al (2000), Robbins and Gindling (1999), Beyer et al, 1999), though not in all such countries (Gonzaga, Filho, Terra, 2002) - the opposite of what trade between advanced and less advanced countries should produce. One plausible explanation is that skilled workers in LDCs are akin to less skilled workers in advanced countries (Robbins, Feenstra and Hanson). The claim that trade increases the size of the informal sector, however, has not been validated. ${ }^{14}$

\section{Regression studies}

"Few economists would doubt the beneficial effects of trade, despite the adverse impact on some groups. Yet the hard evidence supporting such gains from trade - either in a dynamic or static sense - is surprisingly thin." (Feenstra, 2001)

Studies that relate economic performance to trade across countries find that diverse measures of openness are weakly and non-robustly related to growth (Levine and Renalt, 1992).

\footnotetext{
${ }^{13}$ Carlos Salas, "The impact of Nafta on wages and incomes in Mexico". Economic Policy Institute, table 2-2 shows a drop in wage employment in urban areas from $74 \%$ in 1991 to $61 \%$ in 1998

${ }^{14}$ Penelope Goldberg and Nina Pavcnik, "The Response of the Informal Sector to Trade Liberalization" NBER WP 9443, Jan 2003, report that trade raised informal sector employment in Columbia, "but only for the period preceding a major labor market reform that increased the flexibility of the Colombian labor market" and rejected the notion that the rise in the informal sector in Brazil was due to trade liberalization
} 
Using a panel design Harrison found that some measures of trade are related to growth but that others were not related. Rodriguez and Rodrik (2001) note flaws in several analyses that link trade policy measures of openness to growth, which suggests that positive results depend critically on specification and measurement. When researchers add measures of other country policies and institutions to regressions linking growth to openness, the coefficient on openness invariably weakens. Particular measures (the Sachs-Warner openness variable, for instance) may give the desired result that trade increases growth in some regressions, but not in others, and other equally valid measures do not show the expected positive link in almost any case. Using three separate indicators and a dynamic panel framework Greenaway, Morgan and Wright (2002) find that liberalisation has a modest positive lagged effect on growth in developing countries. By contrast, Yanikkaya (2003) finds that trade barriers are positively associated with growth, especially for developing countries.

Most disappointing is the failure of seemingly simple demonstrations that "globalizers", defined as countries that reduce trade barriers and/or expand trade, have better growth records than other countries. The definition of who is a globalizer varies from researcher to researcher (compare Rodrik,1999 with Dollar and Kraay, 2000) and even in the same paper from revision to revision (compare Dollar and Kraay, 2000 with Dollar and Kraay 2001), with correspondingly disparate findings. Since Dollar and Kray's globalizers had higher tariff rates than nonglobalizers in the 1990s as well as in the 1980s (Dollar and Kray, figure 2) and lower ratios of trade to GDP in both decades (figure 2), moreover, it is unclear how to interpret differences among the groups. ${ }^{15}$ The statement that low tariffs and trade are bad for growth is as consistent with the data in the figures as the claim that reductions in tariffs and increases in growth are good

\footnotetext{
${ }^{15}$ In the 1990s globalizers reduced the rate of tariffs more than the non-globalizers, and increased trade/GDP, but the non-globalizers also reduced tariffs, by a comparable percentage amount, while experiencing a drop in
} 
for growth. ${ }^{16}$ What is needed is a general equilibrium model of how the entry of China and India into the global economy. In any case, the collapse of Argentina, a country on all lists of globalizers, devastates any simple comparisons.

Even if research found a strong relation between trade and growth, this would not prove that trade caused growth. Causality could easily run the other way. Frankel and Romer's (1999) innovative use of the geography of countries to instrument for the independent effect of trade represents an interesting effort to identify causality. Successful or not (see Rodrik and Rodriguez for a criticism), however, this approach does little to inform the trade wars debate. This is because there is no reason to expect that policy-induced trade would affect growth in the same manner as geographically-induced trade. Since Zambia cannot readily move to Europe (though its people can migrate), knowing that trade due to nearness to Luxembourg affects growth does not do much to help the case for WC globalization.

\section{Country cases}

Bhagwati and Srinivisan (1999) have argued that we are more likely to uncover the effects of trade in country case studies than in econometric analysis. Labor economists have long found virtue in case studies - if you can't give me at least one real world example of whatever you claim (and preferably more), I don't care how sophisticated you make your model or statistics, I will be sceptical. But there are many countries and many liberalizing cases that take place over different time periods. Case studies may correctly capture something about Korea in the 1960s, when China and India were outside the global economy - but which has little relevance to, say, Cote D'Ivoire in the 1990s, when China and India are major exporters. Greenaway's (1993) review of World Bank case studies of 36 liberalisation episodes from 1950-

${ }^{16}$ Since the relation between reductions in tariffs and increases in growth is not robust, I do not pursue these 
1982 notes many other methodological problems with case analyses and directs attention at the danger that analysts devoted to the trade produces growth view of the world will see "liberalising foreign trade through rose-tinted glasses." Many things are usually changing in a country in addition to trade policies, so ascribing causality through a case approach requires great care, knowledge and judiciousness.

In any case, my reading of country cases is that they do not line up on one side or the other of the trade wars. Granted that Hong Kong succeeded with openness policies; that Singapore did as well, although under much greater government control; that Korea grew through increased exports, though again with considerable government control and a national industrial policy, and that Taiwan benefited from openness. But South Africa did just about everything the World Bank wanted it to do as part of its GEAR (Growth, Employment, and Redistribution) program and failed to deliver either growth, employment or redistribution. When I was with the South African Labour Commission, we wanted the central bank to devalue the rand to increase exports and growth. If only the rand devalued, South Africa would enjoy rising employment. In the 1990 s, the rand lost over half its value relative to the dollar, but South Africa still failed to grow. Argentina followed IMF dictates to such an extent that the Fund invited President Menem to be one of two main country speakers at its1998 Annual Meetings. He stated "...we have worked side by side with the IMF, the World Bank, and the InterAmerican Development Bank (IDB), to achieve macro-economic stability, deepen structural reforms, and adopt policies aimed .. (at) the poorest members of society." ${ }^{17}$ In 1999 Argentina began its economic collapse. Any study of the Argentine crisis is a "a humbling experience for

\footnotetext{
interpretations.

17 President Carlos Menem, Argentina, Oct 6, 1998 Annual Meeting, Board of Governors IMF IMF, Summary Proceedings, 1998, p. 10 (www.imf.org/external/pubs/ft/summary/53/)
} 
policymakers, investors, academics." 18

\section{Retreat of WC globalizers on trade}

When I started preparing this lecture, I feared that many trade specialists would dismiss the claim that trade is not the critical driver of economic outcomes as either nuttier than a fruitcake or incendiary. The babbling of the labour economist who cannot spell Rybicinski. Instead, I have found that many defenders of openness WC style now read the evidence much as I have, though they put a different spin on the empirical findings. Their claims no longer focus on trade per se but on a host of good policies, of which openness is only one. Consider the following two statements by economists deeply committed to the beneficial effects of trade:

" institutional quality - defined as the rule of law, the effectiveness of the government and so on - is also an important determinant of cross-country variation ... it is .... difficult to separate the effects of openness and institutional quality" ("Lifting all boats: why openness helps curb poverty" Andrew Berg and Anne Krueger (2002).

"the available empirical evidence does not support this claim" (p 28) (that lowering taiff barriers will raise growth) but also requires "... other policy changes aimed at eliminating large government deficits, curtailing monetary policy, maintaining market-oriented exchange rates, increasing competition among domestic firms, reducing government corruption, improving the education system, strengthening the legal system, and so forth" (Robert Baldwin, 2003)

Theorists have moved from the evidence that institutional differences and other policies greatly affect outcomes to consider whether institutional differences may seriously impact whether trade is beneficial for an economy at all. Krishna, Mukhopadhyay and Yavas (2002) argue that trade can have deleterious effects when factor markets are distorted whereas the same trade will contribute to growth in a non-distorted labor market. The empirical issue is how much deviation from some competitive ideal is needed to turn the positive effects of trade into negative effects. Hopefully, trade's good effects are robust across many institutional arrangements, but there are no empirical studies regarding this point. It is the "so on"s and "so forth's" that seem to

\footnotetext{
${ }^{18}$ Ricardo Hausmann and Andres Velasco, The Argentine Collapse: Hard Money’s Soft Underbelly, April 26, 2002
} 
have carried the day.

\section{Immigration Has Larger Impacts On Labour Market}

International financial agencies and trade economists think of globalization largely in terms of trade and capital flows, and leave immigration on some back burner. There are several reasons for this. Trade treaties are negotiated internationally by government agencies with no responsibility for immigration. The IFIs deal exclusively with trade and capital issues. Most countries have committed themselves to greater openness via trade or capital markets but want control over immigration - a position that seems to resonate well with their citizens, most of whom support globalization in trade but not in immigration. ${ }^{19}$ Finally, there has been a division of labour in which labour economists use micro-data sets to study immigration while trade economists use firm/product and financial data to study trade and capital flows.

The statement that immigration has more important impacts on the labour market than trade is meaningless in some models. In a standard Hecksher-Ohlin trade model, one cannot analyse trade and factor flows independently. Both are ways to equalize factor proportions, implicitly in the case of trade, explicitly in the case of immigration or capital flows. Mundell (1957) treated immigration and trade as perfect substitutes. If a country restricts immigration, this induces trade flows; if the country enacts tariffs, this induces immigration. It is only by restricting trade, immigration, and capital flows that a country truly distances itself from the global economy. In newer trade models that base trade on increasing returns or differences in technology across countries, immigration plays a larger and more distinct role. Technology transfer through persons trained in advanced countries to LDCs can greatly improve the well-

\footnotetext{
${ }^{19}$ A 2003 Pew Center poll found that the majority of citizens in most countries believed that "growing trade and business ties between (their country) and others was a good thing. A substantial minority, however, believed that working conditions and the gap between rich and poor had worsened as a result of their country being more connected to the world through trade A majority wanted to restrict entry into their country more.
} 
being of LDCs at some cost to the advanced country. Immigration from LDCs to advanced countries that spreads advanced technology over more workers reduces the terms of trade of advanced countries, potentially costing them a lot (Davis and Weinstein, 2002). But the flow of highly educated workers from LDCs to advanced countries can improve the well-being of advanced countries while removing the most able from LDCs.

In a factor proportions framework, the natural tool for comparing the effects of immigration and trade are factor content calculations, where one can measure the implicit impact of trade on factor proportions. Analysis by Borjas, Katz, and myself $(1992,1997)$ found that immigration contributed more to changing US factor proportions in the 1980s and 1990s than did trade. Unskilled immigrants, particularly from Mexico, increased the ratio of unskilled to skilled workers by some $20 \%$ whereas trade flows have increased the (implicit) ratio by about $4 \%$. In countries with a more balanced distribution of immigrants or with fewer immigrants, such as the UK, trade might turn out to be more important than immigration, though I am doubtful.

There are several reasons why trade has modest effects on a nation's implicit factor proportions compared to immigration. First and foremost, of course, is that much of trade is among advanced countries, who have similar factor proportions, while much immigration is from LDCs to advanced countries. Second, the differences in skill mix across industries are not as stark as one might imagine. In the US Borjas, Katz, and I (1997, table 4) estimated the skill mix associated with imports and exports by taking a weighted average of the skill distribution of industries, using the industries share of imports or exports as weights. We found that $22.5 \%$ of employees associated with imports were high school dropouts compared to $17.0 \%$ of employees associated with export industries; whereas $15.9 \%$ of workers associated with imports were college graduates compared to $20.5 \%$ of workers associated with exports. The difference in skill 
mixes between import and export sectors is substantial but far from overwhelming. Industries that export still hire a sizable number of unskilled workers, while industries that import hire a sizeable number of skilled workers. Compared with this, immigrant flows are more disparate, at least in the US due to large numbers with less than high school education coming from Mexico and other LDCs.

Over time immigration has a larger effect on factor proportions than trade because immigrant flows cumulate to stocks, whereas trade is an annual flow. A 1\% immigrant flow for 10 years produces an immigrant share of the work force of 10\% (assuming no return migrants) whereas a trade flow that produces a $1 \%$ increase in implicit labour supply in a year produces that $1 \%$ increase in supply annually. Finally, whereas some goods have little or no domestic competition (think coffee) and non-traded goods and services have no foreign competition (think grocery stores), immigrants compete with native workers across the boards, in non-traded as well as in traded goods sectors.

The evidence that immigration has had bigger effects on skill proportions in labour markets than does trade does not mean, however, that immigration necessarily has large effects on wages. Analyses of massive flows of immigration into particular geographic areas find at most modest reductions in the wages of workers for whom the immigrants are most likely to be substitutes. Borjas, Katz and I (1996) entitled one of our efforts to find effects across geographic areas "Search for the Effect of Immigration on the Labor Market " and came up, as had many other researchers, empty-handed. The most striking evidence is Card's (1990) study of the Mariel boat lift to Miami, which showed that this large unexpected migrant flow had virtually no effects on the market for low skilled workers in that city. Seeking to explain the negligible impact of immigration across geographic areas, Borjas, Katz, and I (1997) noted that the huge 
immigration to California was associated with a decline of internal migration to the state, which would act to disperse the effects of immigration across the US. This view, while consistent with some other research (Filer, 1992), is not supported in other work (Card and DiNardo, 2000). Approaching the finding from a trade perspective, Gaston and Nelson (2000) interpret the small effects of immigration on wages as the result of responses of the distribution of industrial output to immigration that make factor-prices relatively insensitive to the immigrant flows. Immigrants arrive and entrepreneurs set up businesses to use their skills. That something of this sort operates can be seen in the rise of the apparel in Los Angeles and New York coincident with the flow of low skill immigrants. But Borjas (2003) finds that when workers are divided by education and experience, longitudinal analyses of US Census data show that immigration has a sizable impact on the wages of native workers, with elasticities comparable to those in time series studies of the effect of labour supplies on relative wages.

In any case, my claim that immigration has a bigger effect on the labour market than trade depends not on the magnitude of the immigration effect, but on the fact that immigration changes national factor proportions more than trade. Both could have modest effects on wages, with immigration having a larger impact than trade.

How immigration affects sending countries has received less empirical attention. By reducing labour supply in the sending country, emigration should raise wages. Consistent with this, Hanson (2003) finds that the most powerful variable affecting 1990-2000 changes in wages among states in Mexico was the state-US migration rate. This variable trumps state GDP growth, FDI share of sate GDP and import share of state GDP.

\section{Capital Mobility Is Dangerous}

On May 27, 2003, a group of economists held a conference in Washington DC that asked 
"Is Financial Globalization Harmful for Developing Countries?" The discussion paper at the meeting concluded that "it has proven difficult to find robust evidence in support of the proposition that financial integration helps developing countries to improve growth and to reduce macroeconomic volatility"and noted the risk and danger to countries in the early stages of financial integration of higher volatility of output and capital ${ }^{20}$. Who is this group? Radical economists associated with anti-globalization protestors? Trouble-makers from trade unions who can't spell Rybicinsky? Would you believe the International Monetary Fund?

The IMF has not recanted its previous views -- international organizations rarely admit being wrong - but there has been a sea change in its thinking about global capital markets. Consider, for example, as the following two statements from the Fund's Managing Directors.

"in an open market you will have massive capital flows, but the experience of the world, particularly during these last five or six years, is that these massive capital flows have been a positive development, helping developing countries in their very rapid expansion. " Managing Director Camdessus April $1997^{21}$

"the globalization of financial markets has been accompanied by devastating financial crises in emerging market economies. The causes of these crises are complex. However, a common feature has often been over-indebtedness and massive reversals in capital flows, leading to severe recession accompanied by a sharp rise in unemployment." Managing Director Köhler May, 2003. ${ }^{22}$

In theory, global capital markets send capital from advanced countries to poor countries, raising the amount of capital per worker in those countries and their wages. ${ }^{23}$ But in many LDCs, the flow of capital has not gone the expected way, and the major importer of foreign capital has been the US, whose stability and technological progress has attracted foreign investment and allowed a huge trade deficit and that could permit an equally massive federal

\footnotetext{
${ }^{20}$ E. Prasad, K Rogoff, Shang-Jin Wei, M.A. Khose "Effects of Financial Integration on Developing Countries: Some Empirical Evidence," IMF March 17, 2003 http://www.imf.org/external/np/res/docs/2003/031703.pdf/. p 10, p 11.

${ }^{21} \mathrm{http}: / /$ www.imf.org/external/np/tr/1997/tr970428.htm

${ }^{22}$ Horst Köhler The Challenges of Globalization and the Role of the IMF Humboldt University Berlin, May 15, 2003 http://www.imf.org/external/np/speeches/2003/051503.htm

${ }_{23}$ Pierre-Olivier Gourinchas and Olivier Jeanne argue that the welfare gain from switching from financial autarky to perfect capital mobility is modest in a typical emerging economy, even without allowing for the risk that such
} 
budget deficit. Net foreign investment in LDCs has been modest, concentrated in a few countries. Some major LDCs like China run huge balance of trade surpluses, which necessitate capital outflows. The wealthy in LDCs invest substantially in advanced countries as a safeguard against corrupt governments and insecure property rights or currency fluctuations. On the order of 100 billion dollars of private Argentine capital, for instance, resides outside the country.

The claim that open capital markets create risk without delivering clear benefits is based on a growing body of empirical research on the link between financial liberalization and economic progress. Diverse studies have found that financial liberalization increases the chance of a banking and currency crisis, which have substantial economic costs. The 1994 Mexican peso crisis, the 1997-98 Asian financial crisis, and the 2001 Argentine meltdown, being cases in point. Aizenman (2002) estimates that a currency crisis costs a country 8\% of GDP and that a currency and banking crisis cost it 18\% of GDP. Nothing short of a civil war could have such impacts in a short period of time.

The failure to give LDCs protection against the risk of volatile capital flows is the major failure of the international capital market. Instead of providing financial instruments for risk management (Shiller, 2003), the global capital markets place risk on the developing countries. Most LDCs cannot raise money in international capital markets in their own currency, even in the form of indexed bonds which would eliminate the risk to investors that the country would inflate its currency to avoid paying the debt. One of the few exceptions was Mexico's Tesobonos short term debt instruments, which the US treated differently than other debts in its financial rescue package for Mexico. In crisis or in expectation of a financial crisis, the private capital market demands extraordinarily high interest rates to cover the risks to LDCs - the 
opposite of an insurance system. Global capital markets create an "exit" option for domestic capitalists that could be harmful to economic development, since those capitalists may have country-specific knowledge as well as political voice to steer countries toward better economic policy that foreign capitalists may lack. European countries recovered from World War II with capital controls that they did not remove until the 1960s or later, but global financial institutions have discouraged developing countries from controlling the flow of domestic or foreign capital.

On the other side, the gains of financial opening on growth are elusive in empirical work. In their review, IMF economists identified 14 studies of the relationship between financial opening and growth: only three studies found positive effects of financial liberalization on output. The IMF also contrasted the growth rate of real GDP per capita against a measure of capital account openness for 1982-1997 and found no relation. ${ }^{24}$ At the same time, FDI is associated both with domestic investment and growth, though it may simply be responding to good economic conditions in a country. Even if financial integration positively impacted on growth, however, it is unclear that IMF loans or stabilization programs help countries access the global capital market. Some studies like LI (2003) show that IMF programs do little to improve access; others note that the ability of programs to imrove access for countries depends on the conditions under which it makes the loan - commitment to reforms and other policies ... the so forth and so on.

In sum, under the current world financial architecture, international capital markets place normal citizens in poor countries at risk without assuring them of compensating benefits. And

\footnotetext{
${ }^{24}$ Prasad, et al. Table 3 Figures 6 and 7. The IMF researchers contrasted financial integration of the fastest and slowest growing economies from 1980-2000. Seven of the ten fastest growing economies were financially integrated compared to three of the ten slowest growing economies. But this differential is unlikely to persist in a multi-variate analysis that included a measure of governance or political stability The slowest growing countries included Haiti, Niger, Burundi, Venezuela, Togo, Peru, and Cote D'Ivoire as well as the more stable Jordan, South Africa, Ecuador, and Paraguay. See Prasad, et al. table 2.
} 
the global financial powers rarely consider schemes designed to improve risk management, be it a Tobin tax to reduce the volatility of capital ${ }^{25}$ or an international bankruptcy court. ${ }^{26}$

\section{Labour Standards Rise Under Globalization}

There are two conflicting fears about the relation between trade and labour standards.

Free trade advocates fear that standards are protectionism in disguise that would undermine LDC trade. Advocates of standards fear that poor standards in some countries will undermine standards in other countries. Both fears are wrong.

The global trading community regards the anti-sweatshop activists who seek global labour standards as naive or disingenuous protectionists:

"The talk of "exploitation", failure to pay a "living wage" ... (is) little more than cynical manipulation of our moral instincts and an obfuscation of the reality to pursue our economic interest while creating the illusion that we are helping the victims instead." (Bhagwati, 2000)

"The demand for linkage between trading rights and the observance of standards with respect to the environment and labour would seem to arise largely from protectionist motivation." (Srinivasan, 1994, p 36)

"The real danger of using trade sanctions as an instrument for promoting basic rights is that the trade-standards link could become highjacked by protectionist interests attempting to preserve activities rendered uncompetitive by cheaper imports." (World Bank, World Development Report 1995, p 79).

"Western countries openly propose to eliminate the competitive edge of East Asia... professed concern about workers' welfare is motivated by selfish interest." (Mahathir bin Mohammed )

Elliott and Freeman (2003) examine the fear that campaigns to improve labor standards are protectionism in disguise and find it groundless. The movement for global standards comes from consumers, students, and activists who are willing to pay more for items produced in LDCs

\footnotetext{
${ }^{25}$ This is not to endorse a Tobin tax on transactions, which faces problems of implementation, but simply to remark on limited attention to any schemes to reduce volatility.

${ }^{26}$ Anne Krueger's proposed bankruptcy court got nowhere in 2002, despite the Argentina crisis. There was a similar lack of response to Jeffrey Sach's 1995 proposal for such a court.
} 
under good conditions, ${ }^{27}$ not from firms or workers who produce items that compete with LDC goods. The activists make it clear that the worst thing for the firms they target to do would be to withdraw production from LDCs. As for the unions in advanced countries who are often associated with anti-sweatshop groups, they know that jobs and sectors have shifted permanently to the LDCs. Union workers are disproportionately employed in high skill export industries, not in low wage import industries. Their economic interests lie in free trade not in protectionism. When they believe members can benefit from protectionism, they do not hide their intentions: they unabashedly seek protection from trade, as the US steel union did in 2001, when it struck a deal with the Bush administration. ${ }^{28}$

Motivation aside, improved standards in LDCs might still raise costs greatly in the formal sector and thus curtail the growth of employment and output. In fact, firms can meet most standards at relatively low cost, with little impact on employment and growth and can potentially pass the costs on to consumers in advanced countries who want those standards. Providing decent treatment at work in the form of emergency exits or lights in a workplace or fire extinguishers or giving workers security from sexual or other harassment or the right to go to the toilet cannot cost much. As for the standards that may cost the producer considerably, such as Nike' investing millions in making its Indonesian shoe factory safe from chemical fumes, even these numbers pale relative to the cost of the final price of the item, given the small share of cost of production in LDCs to those items.

Regression studies using cross-country data have found little or no link between measures

\footnotetext{
${ }^{27}$ The willingness of consumers in advanced countries to pay more for products made under better conditions in LDCs means that higher standards can increase the flow of money to those countries. If LDCs could organize around global standards, they could alter the terms of trade in their favor by jointly passing on to advanced countries the cost of higher standards through higher export prices.

${ }^{28}$ One could argue that advocates motivated by protectionism could by chance produce a level of global standards that would improve the well-being of workers in LDCs, as an unintended consequence, but I doubt that even persons favorable to standards would accept such an argument.
} 
of standards, usually indexed by the number of ILO conventions a country has signed, and labour costs, foreign direct investment (FDI) or related outcomes. Although this conclusion fits my expectations, I put little weight on it, because the data are too aggregative and subject to measurement error to yield any firm conclusions. The number or kind of ILO Conventions that a country has signed is at best weakly related to actual standards, so that weak correlations could simply reflect measurement error. ${ }^{29}$ What is needed are careful company or plant level case studies using firm data on the actual costs of improving standards.

\section{Race to the bottom?}

The notion that low standards in some countries leads to a race to the bottom in standards -- social dumping - does not stand up to criticism. The proposition assumes that standards raise costs of production sufficiently to impose a competitive disadvantage on producers with higher standards. Initially, the argument was that bad standards in LDCs would drive out good standards in advanced countries, but given the different goods produced between advanced countries and LDCs, it is more plausible to worry that bad standards in some LDCs might drive out good standards in other LDCs.

The race to the bottom argument ignores the ways in which a country can maintain standards in the face of competition. Part of the cost of standards will, after all, fall on workers, who prefer higher to lower standards. A mandated increase in benefits shifts the supply of labour (making it more attractive for workers) and the demand for labour (raising costs), where the schedules are measured with respect to wages only. The extent to which the cost falls on

\footnotetext{
${ }^{29}$ Three of five studies relating measures of ratified ILO conventions find no relation (OECD, 1996; Kucera, 2002); Flanagan (2002). Rodrik (1996) measured standards by the number of ratified ILO conventions and by US embassy reports on lax child labor standards and found that the number of conventions and superior child labor standards were associated with higher labor costs, but were not linked to exports and found that US FDI was greater in countries with better child labor standards. Maskus (2003) found the labor standards were positively related to export performance in East Asia. Flanagan interprets his result that "international labor standards do not influence labor costs, exports, and foreign direct investment" as indicating that standards are symbolic, but it could be that
} 
employers or workers is an issue of incidence comparable to that of the incidence of taxes. In addition, some standards that raise short term costs to firms may have greater benefits than costs for an economy over the long run. Child labour laws, laws requiring children to attend school, and the like, increase human capital formation at the expense of higher costs of production for firms that employ children. Some health and safety regulations, which reduce injuries and fatalities, may also pay for themselves at the national level, although not at the firm level. With flexible exchange rates, moreover, economies can adjust to different standards through changes in exchange rates. If Brazil wants to spend more on occupational health and safety standards than China, and if some of the cost of those standards falls on firms, Brazilian firms will be at a competitive disadvantage at a given exchange rate. But then the Brazilian currency will depreciate relative to the Chinese currency, and all Brazilians will bear the cost of the higher health and safety standards through the higher cost of imports. Countries can choose the level of standards they want.

Conceptual arguments aside, the fact is that labour standards have risen with globalization. Standards have risen in advanced countries in the post World War II period while trade has increased among those countries and between them and LDCs. Economic problems have caused some standards like minimum wages to decline in some LDCs, but countries continue to sign up to ILO conventions, which commit them to improving standards. Harrison and Scorse (2003) find that in Indonesia during the period of human rights activism there was a significant upward trend in compliance with minimum wage legislation among exporting industries, particularly in the garment and apparel sectors on which anti-sweatshop activists focussed their attention. ${ }^{30}$ ILO Convention 182, against the worst forms of child labour, was

${ }^{30}$ Ann Harrison and Jason Scorse "The Impact of Globalization on Compliance with Labor Standards: A Plant-Level 
ratified by 74 countries in just two years. In their analysis of the impact of liberalized trade policy on child labour, Edmonds and Pavcnik (2003) found that in Vietnam price increases in rice associated with the elimination of an embargo on exports reduced child labour in the 1990s, largely because families became wealthier.

Finally, the evidence that foreign-owned firms tend to pay higher wages and offer better working conditions than domestic firms or in agriculture, shows that globalization improves rather than reduces labour standards. ${ }^{31}$ Because even bad working conditions in multinationals or their subsidiaries in export sectors are better than working in agriculture, the export sector has a continuous flow of labour applicants.

\section{Conclusion: The Cost of Exaggerated Claims}

If one accepts my main theme - that the trade wars has exaggerated the impact of trade on economies - two questions naturally arise - why? and does it matter? Why have proponents and opponents of trade WC style exaggerated claims about the effects of trade? Have the exaggerated claims done any harm?

A "conspiracy interpretation" of the exaggeration by proponents of trade treaties and open markets is that their real intent is to increase the power of capital and reduce the scope for governments to redistribute income to lower wage workers. In this sense, they resemble recent tax cuts in the US: sold as something to spur the economy and create jobs, but designed largely to redistribute income from the middle class to the super-wealthy. A similar "conspiracy interpretation" of the exaggerated costs of trade by opponents of trade treaties and open capital markets is that they are old-line leftists who oppose free markets and capitalism and use the globalization issue as a means for furthering their otherwise discredited views.

${ }^{31}$ Drusilla Brown, Alan Deardorff and Robert Stern "The Effects of Multinational Production on Wages and 
A less cynical view is that political debate require analysts to exaggerate costs and benefits to attract the attention of the public. If Ross Perot had campaigned against NAFTA by saying "it's not going to be as good as the Administration says, and there will be some real costs", he would not have won the attention that the great sucking sound gave him. Similarly, if the Clinton Administration and supportive economists had said "some will gain and some will lose, but the gainers will make more than the losers will lose (and might contribute to our political party) and neither the gains nor losses will be big enough to measure afterwards", they might not have convinced Congress to enact the legislation. Economists who engage in public debate must weigh the benefits of strongly supporting their side and getting attention against the costs of losing professional credibility. Borjas, Katz, and I were happy to see our work on the effects of trade cited by both sides in the debate, but upset when the same work was attacked by both sides.

Another possible reason why economists oversold the advantages of export-oriented openness may be an intellectual rebound from the failure of import substitution strategies in the previous decade. The successes of East Asia and later China and India as they entered the global economy raised the possibility that perhaps there was a single path toward economic growth, and that the WC had found it.

Did the hype about the benefits or costs of trade do the global economy any harm? It gave the public, policy-makers, and researchers an unrealistic view of the role of trade in economic development and growth. It led some to see trade as the solution to problems, when at most it is a start to solutions. It led others to see trade as the star villain when in fact it is a bit player. But perhaps the public balanced out the two extreme views. Despite the rhetoric around particular treaties and issues, people around the world seem to have come out reasonably 
favorably inclined to globalization and favorably inclined to labour standards - which I find reassuring.

But there still was a cost to the exaggerated argument in the trade wars. The cost is that debate focused on trade issues and adding labour standards to trade treaties rather than on the more problematic capital flows. Protestors did not demand reforms in volatile capital markets and indebtedness with the vigor they opposed trade treaties that lacked labour standards clauses. Free traders did not trouble over the architecture of the global financial system as much as they did about the alleged risk of adding labour standards to trade treaties, though Bhagwati expressed grave concerns over open capital markets. Neither side asked for freer flows of immigrants. As a result little has been done to restructure world capital markets to reduce volatility and risk, and immigration policies are not part of the globalization debate. With the retreat of the WC globalizers from their strong claims about trade and their recognition of the problems of open capital markets, hopefully the trade wars will transmute into the global capital market wars and the agricultural subsidy wars in the near future. Rybczynski. 


\section{Bibliography}

Aizenman, Joshua. 2002. "Financial Openings: Evidence and Policy Options" NBER Working Paper 8900 (April).

Andrews, Donald. 1993. "Tests for Parameter Instability and Structural Change With an Unknown Change Point," Econometrica, vol 61, no 4 (July), pp 821-856.

Baldwin, Richard. 1989. "The Growth Effects of 1992" Economic Policy no 9, (Oct) pp 247-281.

Baldwin, Robert. 2003. “Openness and Growth: What's the Empirical Relationship" NBER Working Paper 9578 (March).

Berg, Andrew and Anne Krueger. 2002. "Lifting all boats: why openness helps curb poverty," Finance and Development, vol 39:3 (Sept).

Beyer, H. Rojas, P and Vergara, R 1999 “Trade Liberalization and Wage Inequality” Journal of Development Economics, vol 59, pp 103-123

Bhagwati, Jagdish. 1995. "Trade Liberalisation and 'Fair Trade' Demands: Addressing the Environmental and Labour Standards Issues.” The World Economy, vol. 18: 745-59.

Bhagwati, Jagdish. 2000. The Financial Times, May 1.

Bhagwati. J. and Srinivasan, T.N. Outward-Orientation and Development: Are the Revisionists Right?"(September 1999, http://www.columbia.edu/ jb38/Krueger.pdf

Blustein, Paul. 2003. “ Bankruptcy' System for Nations Fails to Draw Support” Washington Post, April 2.

Blustein, Paul. 1996. "NAFTA: free trade bought and oversold”, Washington Post, Sept 30, p A01.

Bolkestein, Frits. http://europa.eu.int/comm/internal_market/10years/index_en.htm

Borjas, George, Richard B. Freeman and Lawrence F. Katz. 1997. "How Much Do Immigration and Trade Affect Labor Market Outcomes," Brookings Papers on Economic Activity Vol 1, pp: $1-90$.

Borjas, George, Richard B. Freeman and Lawrence F. Katz, 1996." Searching for the Effect of Immigration on the Labor Market, American Economic Review, vol 86, pp.246-251

Borjas, George, Richard B. Freeman and Lawrence F. Katz. 1992. "On the Labor Market Effects of Immigration and Trade", in G. Borjas and R. Freeman (eds.), Immigration and the Work Force: Economic Consequences for the United States and Source Areas (University of Chicago 
Press for NBER).

Borjas, George, 2003 “The Labor Demand Curve is Downward Sloping: Reexamining the Impact of Immigration on the Labor Market”, NBER Working Paper No. w9755

Brown, Drusilla, Alan V. Deardorff, and Robert M. Stern. 1996. International Labor Standards and Trade: A Theoretical Analysis. In Jagdish N. Bhagwati and Robert E. Hudec, eds., Fair Trade and Harmonization: Prerequisites for Free Trade? (Cambridge, MA: MIT University Press).

Brown, Drusilla, Alan V. Deardorff and Robert M. Stern. 2003. "The Effects of Multinational Production on Wages and Working Conditions in Developing Countries NBER WP 9669, April.

Card, David (1990) “ The impact of the Mariel Boatlift on the Miami Labor Market”, Industrial and Labor Relations Review vol 43, pp 245-257

Card, David, and Dinardo, J (2000) "Do Immigrant Inflows Lead to Native Outflows?" American Economic Review Vol(90, 2), pp 360-367

Cecchini, P. 1988. The European Challenge 1992: the benefits of a Single Market (Aldershoot UK, Wildwood House, Ltd).

Davis, Donald and Weinstein, David "Technological Superiority and the Losses from Migration” NBER working paper 8971, May 2002

Deardorff, Alan (2003) "What Might Globalizations Critics Believe?" The World Economy, vol 26, pp 639-658

Dobson, Wendy and Gary Hufbauer. 2001. "World Capital Markets, challenge to the G-10." Institute for International Economics (May).

Dollar, David and Aart Kraay. 2000. "Growth Is Good for the Poor,” World Bank Policy Research Working Paper 2587.

Dollar, David, and Aart Kraay. 2001. "Trade, Growth, and Poverty.” World Bank Policy Research Working Paper 2615.

Edmonds, Eric and Nina Pavcnik. 2002. "Does Globalization Increase Child Labor? Evidence from Vietnam" NBER Working Paper 8760 Feb.

Elliott, Kimberly Ann, and Richard B. Freeman. 2003. Can Labor Standards Improve Under Globalization? (Washington: Institute for International Economics) (forthcoming)

Feenstra, Robert. 2001. Program Report, The International Trade and Investment Program, NBER Reporter, Winter 2000/2001 
Feenstra, Robert, and Gordon Hanson. 2001. "Global Production Sharing and Rising Inequality: A Survey of Trade and Wages." National Bureau of Economic Research Working Paper No. 8372. Cambridge, MA.

Feliciano, Zadia. 2001. "Workers and Trade Liberalization: The Impact of Trade Reforms in Mexico on Wages and Employment," Industrial \& Labor Relations Review, Vol. 55 (1) (October), p 95-115

Filer, Randy 1992 "The Effect of Immigrant Arrivals on Migratory Patterns of Native Workers" in G. Borjas and R. Freeman "Immigration and the Work Force" (University of Chicago Press,/NBER), pp 245-269

Flanagan, Robert J. 2002. "Labor Standards and International Competitive Advantage." Prepared for the Confrence on Labor Standards, Stanford University, May.

Frankel, Jeffrey A., and David Romer.1999. "Does Trade Cause Growth?” The American Economic Review, vol. 89, no. 3 (June): 379-99.

Freeman, Richard B. 1993. "Labor Market Institutions and Policies: Help or Hindrance to Economic Development?" In Proceedings of the World Bank Annual Conference on Development Economics 1992. Washington: World Bank.

Freeman, Richard. 1994. "A Hard-Headed Look at Labour Standards" in W. Sengenbergee and D. Campbell (eds), International Labour Standards and Economic Interdependence ILO.

Gaston, Noel and Delson, Douglas (2000) "Immigration and Labour Market Outcomes in the US: a political economy puzzle" Oxford Review of Economic Policy, volume 16, pp 104-114.

Goldberg, Penelope and Nina Pavcnik. 2003. "The Response of the Informal Sector to Trade Liberalization" NBER WP 9443 (Jan).

Gonzaga, Gustavo, Naércio Menezes-Filho, and Christina Terra. "Wage Inequality in Brazil: the role of trade liberalization" http://www.econ.puc rio.br/PDF/papertrade8.pdf, Sept 27, 2002

Gourinchas, Pierre-Olivier and Olivier Jeanne. 2003. The Elusive Gains from International Financial Integration NBER Working Paper No. 9684 (May).

Green, Francis, Andy Dickerson, Jorge Saba Arbache. 2000. "A Picture of Wage Inequality and the Allocation of Labour through a period of trade liberalisation: the Case of Brazil." University of Kent Department of Economics, Study 00/13 (December).

Greenaway, David, Morgan, Wyn and Wright, Peter (2002) "Trade Liberalization and Growth in Developing Countries”, Journal of Development Economics, vol 67, pp 229-244

Greenaway, David (1993) “Liberalising Foreign Trade Through Rose-tinted Glasses” Economic Journal, 103, p 208-222 
Hanson, Gordon. 2003. "What Has Happened to Wages in Mexico Since NAFTA?" NBER Working Paper 6563 (March).

Hanson, Gordon and Ann Harrison. 1999. "Who Gains from Trade Reform? Some Remaining Puzzles" Journal of Development Economics, vol 59, pp 125-154

Harrison, Ann and Jason Scorse. 2003. "The Impact of Globalization on Compliance with Labor Standards: A Plant-Level Study (Brookings Trade Forum, April).

Hausmann, Ricardo and Andres Velasco, Harvard University and NBER, Hard Money's Soft Underbelly: Understanding the Argentine Crisis.

http://www.nber.org/ confer/2002/argentina02/argentina_bg.html

http://people_press.org/reports/pdf/185topline.pdf

http://strategis.ic.gc.ca/sc_ecnmy/mera/engdoc/02f.html

http://www.dfait_maeci.gc.ca/nafta_alena/over_en.asp

http: //www.imf.org/external/np/tr/1997/tr970428.htm

http://www.southern.org/pubs/Post_9_11.pdf

Ipsos-Reid. 2003.http://www.ipsos_reid.com/media/dsp_displaypr_cdn.cfm?id_to_view=1839 (June Opinion Poll).

Krishna, Kala, A. Mukhopadhyay, and C. Yavas. 2002. "Trade with Labor Market Distortions and Heterogenous Labor: Why Trade Can Hurt" NBER Working Paper 9086 (July).

Köhler, Horst. 2003. "The Challenges of Globalization and the Role of the IMF," presented at the Annual Meeting of the Society for Economics and Management at Humboldt University Berlin, May 15. http://www.imf.org/external/np/speeches/2003/051503.htm

Kucera, David. 2001. "The effects of core workers rights on labour costs and foreign direct investment: Evaluating the "conventional wisdom."' Discussion Paper \#130, International Institute for Labor Studies.

Krueger, Anne. 2002. "Crisis Prevention and Resolution: Lessons from Argentina" www.imf.org/external/np/speeches/2002/071702.htm

Lee, Thea. 1995. "False Prophets: the selling of NAFTA.” EPI Briefing Paper, http://www.lights.com/epi/virlib/BriefingPapers/1995/falsep.PDF

Levine, Ross, and David Renelt. 1992. "A Sensitivity Analysis of Cross-Country Growth Regressions.” American Economic Review, vol. 82,: pp. 942-63. 
Li, Quan. 2003. "IMF Programs and Financial Liberalization in the Developing World," Presented at the Annual Meeting of the Midwest Political Science Association (April 4).

Mah, Jai S. 1997. "Core Labour Standards and Export Performance in Developing Countries." The World Economy, vol. 20: 773-85).

Maskus, Keith E. 1997. "Should Core Labor Standards Be Imposed Through Trade Policy?" Policy Research Working Paper No. 1817 (August) (Washington: World Bank).

Maskus, Keith E. 2003. "Trade and Competitiveness Aspects of Environmental and Labor Standards in East Asia" Chapter 7 in Kathi Krumm and Homi Kharas East Asia Integrates: A Trade Policy Agenda for Shared Growth (Washington DC: World Bank).

Martin, Will, and Keith E. Maskus. 1999. "Core Labor Standards and Competitiveness: Implications for Global Trade Policy. World Bank, processed, October 4.

Menem, Carlos. 1998. Annual Meeting, Board of Governors IMF

IMF, Summary Proceedings, 1998 (Oct 6), p. 10 (www.imf.org/external/pubs/ft/summary/53/)

bin Mohammed, Mahathir. 1994. International Herald Tribune, 17 May, p 6

Morici, Peter, with Evan Schulz. 2001. Labor Standards in the Global Trading System. Washington: Economic Strategy Institute.

Mundell, Robert, 1957. "International Trade and Factor Mobility" American Economic Review, volume 47, pp 321-335.

OECD.1995. Trade and Labour Standards: A Review of the Issues. Paris.

OECD. 1996. Trade, Employment, and Labour Standards: A Study of Core Workers' Rights and International Trade. (Paris: OECD).

Prasad, E. K Rogoff, Shang-Jin Wei, and M.A. Khose. 2003. "Effects of Financial Integration on Developing Countries: Some Empirical Evidence,” IMF March 17. http://www.imf.org/external/np/res/docs/2003/031703.pdf/

Revenga, Ana. 1995. "Employment and Wage Effects of Trade Liberalization: The Case of Mexican Manufacturing." Working Paper No. 1524. Washington: World Bank.

Robbins, Don. 1994. "Worsening Relative Wage Dispersion in Chile during Trade Liberalisation and its Causes: Is Supply at Fault?" Harvard Institute for International Development Discussion Paper no. 484.

Robbins, Don, and T.H. Gindling. 1999. "Trade Liberalisation and the Relative Wages of More Skilled Workers in Costa Rica." Review of Development Economics 3, 140-154. 
Robertson, R. 2000. "Trade Liberalisation and Wage Inequality: Lessons from the Mexican Experience." World Development, vol. 23: 827-849.

Rodriguez, Francisco, and Dani Rodrik. 2001. "Trade Policy and Economic Growth: A Skeptic's Guide to the Cross-National Evidence." In NBER Macroeconomic Annual 2000. Cambridge, MA: National Bureau for Economic Research.

Rodrik, Dani. 1997. Has Globalization Gone Too Far? Washington: Institute for International Economics.

Rodrik, Dani. 1996. "Labor Standards in International Trade: Do They Matter and What To Do About Them." In Robert Z. Lawrence, Dani Rodrik, and John Whalley, Emerging Agenda for Global Trade: High Stakes for Developing Countries. Policy Essay No. 20. Washington: Overseas Development Council.

Salas, Carlos. 2001. "The impact of Nafta on wages and incomes in Mexico". Economic Policy Institute, EPI Briefing Paper (April) (Washington, DC: Economic Policy Institute). http:/www.ratical.org/co_globalize/NAFTA@7/mx.html

Scheve, Kenneth F. and Matthew J. Slaughter. 2001. Globalization and the Perceptions of American Workers. Washington: Institute for International Economics.

Scott, Robert. 2001. "NAFTA's Hidden Costs”, EPI Briefing Paper (April) (Washington, DC: Economic Policy Institute).http://www.ratical.org/co_globalize/NAFTA@7/us.html

Shiller, Robert. 2003. The New Financial Order: Risk in the 21st Century, (NJ: Princeton University Press)

Srinivasan, T.N., and Jagdish Bhagwati.1999. Outward-orientation and Development: Are Revisionists Right? Festchrift in honor of Anne Kreuger. Yale University, Economic Growth Center Discussion Papers, September.

Srinivasan, T.N. 1994. "International Labor Standards Once Again!” In International Labor Standards and Global Economic Integration: Proceedings of a Symposium. Bureau of International Labor Affairs, US Department of Labor. Washington, July.

Trefler, Daniel "The Long and Short of the Canada-US Free Trade Agreement," NBER Working Paper No. 8293.

Tybout, James and Erkan Erdem. 2003. "Trade Policy and Industrial Sector Responses in the Developing World: Interpreting the Evidence," Brookings Trade Forum, May.

University of Maryland, Program on International Policy Attitudes. 2000. Americans on Globalization: A Study of Public Attitudes. College Park, MD, March. Available at: www.pipa.org/OnlineReports/Globalization/global_rep.html.

Warf, Phillip S. and Steven Kull. 2001. ”Tepid Traders: US public attitudes on NAFTA and Free 
Trade Expansion", University of Alberta School of Business Studies, CIBS-WCER, http://www.bus.ualberta.ca/CIBS WCER/WCER/NAFTAwarf.pdf.

World Bank. 1995. World Development Report 1995.

Yanikkaya, Halit. 2003. "Trade openness and economic growth: a cross-country empirical investigation," Journal of Development Economics , volume 72, pp 57-89. 